\title{
The ecology and bioactivity of some Greco-Roman medicinal minerals: the case of Melos earth pigments
}

\author{
C. W. Knapp ${ }^{1}$ - G. E. Christidis ${ }^{2} \cdot$ D. Venieri ${ }^{3} \cdot$ I. Gounaki $^{3} \cdot$ J. Gibney-Vamvakari $^{4} \cdot$ M. Stillings $^{1} \cdot$ E. Photos-Jones $^{5,6}{ }^{(D)}$
}

Received: 9 February 2021 / Accepted: 30 June 2021 / Published online: 17 September 2021

(c) The Author(s) 2021

\begin{abstract}
Mineral compounds, as pigments and therapeutics, appeared regularly in the technical and medical texts of the Greco-Roman (G-R) world. We have referred to them as 'G-R medicinal minerals' and we suggest that despite their seeming familiarity, there are actually many unknowns regarding their precise nature and/or purported pharmacological attributes. Earth pigments are part of that group. This paper presents a brief overview of our work over the past twenty years relating to: a. the attempt to locate a select number of them in the places of their origin; $b$. their chemical/mineralogical characterization; $c$. the study of their ecology via the identification of the microorganisms surrounding them; $d$. their testing as antibacterials against known pathogens. In the process, and to fulfil the above, we have developed a novel methodological approach which includes a range of analytical techniques used across many disciplines (mineralogy, geochemistry, DNA extraction and microbiology). This paper focuses on a select number of earth pigments deriving from the island of Melos in the SW Aegean, celebrated in antiquity for its Melian Earth, a white pigment, and asks whether they might display antibacterial activity. We demonstrate that some (but not all) yellow, green and black earth pigments do. We also show that the manner in which they were dispensed (as powders or leachates) was equally important. The results, although preliminary, are informative. Given their use since deep time, earth pigments have never lost their relevance. We suggest that the study of their ecology/mineralogy and potential bioactivity allows for a better understanding of how our perception of them, as both pigments and therapeutics, may have evolved.
\end{abstract}

Keywords Ochres $\cdot$ Earth pigments $\cdot$ Jarosite $\cdot$ Melanterite $\cdot$ Manganese oxide $\cdot$ Miltos $\cdot$ Ecology $\cdot$ Antibacterial activity

\section{PREMISE}

This Topical Collection (TC) covers several topics in the field of study, in which ancient architecture, art history, archaeology and material analyses intersect. The chosen

This article is part of the Topical Collection on Mortars, plasters and pigments: Research questions and answers

E. Photos-Jones

effie.photos-jones@glasgow.ac.uk

1 Civil and Environmental Engineering, Strathclyde University, Glasgow, UK

2 Mineral Resources Engineering, Technical University of Crete, Chania, Greece

3 Environmental Engineering, Technical University of Crete, Chania, Greece

4 Adamas, Milos, Greece

5 Archaeology, School of Humanities, University of Glasgow, Glasgow, UK

6 Analytical Services for Art and Archaeology, Ltd, Glasgow, UK perspective is that of a multidisciplinary scenario, capable of combining, integrating and solving the research issues raised by the study of mortars, plasters and pigments (Gliozzo et al. 2021).

The first group of contributions explains how mortars have been made and used through the ages (Arizzi and Cultrone 2021, Ergenç et al. 2021, Lancaster 2021, Vitti 2021). An insight into their production, transport and on-site organisation is further provided by DeLaine (2021). Furthermore, several issues concerning the degradation and conservation of mortars and plasters are addressed from practical and technical standpoints (La Russa and Ruffolo 2021, Caroselli et al. 2021).

The second group of contributions is focused on pigments, starting from a philological essay on terminology 
(Becker 2021). Three archaeological reviews on prehistoric (Domingo Sanz and Chieli 2021), Roman (Salvadori and Sbrolli 2021) and Medieval (Murat 2021) wall paintings clarify the archaeological and historical/cultural framework. A series of archaeometric reviews illustrate the state of the art of the studies carried out on Fe-based red, yellow and brown ochres (Mastrotheodoros et al. 2021), Cu-based greens and blues (Švarcová et al. 2021), As-based yellows and reds (Gliozzo and Burgio 2021), Pb-based whites, reds, yellows and oranges (Gliozzo and Ionescu 2021), Hg-based red and white (Gliozzo 2021) and organic pigments (Aceto 2021). An overview of the use of inks, pigments and dyes in manuscripts, their scientific examination and analysis protocol (Burgio 2021) as well as an overview of glass-based pigments (Cavallo and Riccardi 2021) are also presented. Furthermore, two papers on cosmetic (Pérez Arantegui 2021) and bioactive (antibacterial) pigments (this paper) provide insights into the variety and different uses of these materials.

\section{Introduction}

\section{The pharmacology of G-R medicinal minerals: A methodological approach for the examination of biome-rich minerals}

'Greco-Roman (G-R) medicinal minerals' (G-R MMs) is a term we have put in place to refer to the minerals/minerals combinations that feature in pharmacological preparations in the medical and technical texts of antiquity: Theophrastus (On Stones), Pliny (Natural History, Book 35), Dioscorides (De Materia Medica), Celsus (De Medicina), Galen (many texts), Scribonius Largus (Compositiones), and in numerous commentaries of them throughout the medieval, Renaissance and modern periods. Although most of the c. 90 minerals (minerals combinations and rocks) grouped together in Dioscorides' Book 5 (Beck 2005), appear familiar to the reader, they are actually little understood from the perspective of both their nature (mineralogical/geochemical) and their pharmacological attributes.

There are many reasons for that: some G-R MMs have known geographical places of origin (for example, Lemnian Earth (Mat. Med. V.97) or Melian Earth (Mat. Med. V.159) but their localities of extraction are not specified, making their identification in the field more laborious; for others, the region is too broad or vaguely defined to be of practical use (chrysocolla from Macedonia (Mat. Med. V.89)); for some, the same name is used for both the natural mineral as well as the synthesized one (kyanos, Mat. Med. V.91); some are synthesized pyrometallurgically (lithargyros, Mat. Med. V.87); for others, also artificially produced, a mere cooking hearth would have sufficed (molybdos kekavmenos
(Mat. Med. V.82)), and for yet a third category no heat was required (psimythion (Mat. Med. V.88)). When they do occur as part of pharmacological recipes, it is not clear whether the natural or the synthesized version has been used; it is surmised that the latter would be a 'purer' form of the former.

Therefore, for an assessment of these materials as potential pharmacological agents, it was necessary to break away from the ancient texts and treat G-R MMs as archaeological materials, i.e. like metals, ceramics, glass or metallurgical waste which can be analysed and tested. Given their rarity in the archaeological record our approach involved locating evidence of similar minerals 'deposits' in the field, within the geographical regions of their purported origin; also locating the archaeological evidence (pottery, installations) confirming that these 'deposits' having been worked in the periods of interest (Classical/Hellenistic Roman). Original 'deposits' of G-R medicinal minerals are difficult to locate, first because they were removed via quarrying (rather than mining) and second, contrary to, for example, pyrometallurgical waste, the waste products of their enrichment/ treatment can be mineralogically/chemically near-identical to the source material.

In the course of the last twenty years, we have been pursuing a geoarchaeological approach in locating minerals/ mineral combinations appearing in the G-R texts, in various islands in the Aegean (Photos-Jones and Hall 2011); the red ochre miltos in the island of Kea (Photos-Jones et al. 1997, 2018), Lemnian Earth in Lemnos (Hall and Photos-Jones 2008; Photos-Jones et al. 2017a), Samian Earth in Samos (Photos-Jones et al. 2015), Melian Earth and alum group minerals in Melos (Hall et al. 2003a, b; Photos-Jones and Hall 2014); alumen in Italy, at Campi Flegrei, near Naples (Photos-Jones et al. 2016) and the Aeolian islands (PhotosJones et al. 2017b).

However, gradually and in the process of investigating alum extraction and processing on Melos in the localities worked during the Roman period, aspects of the ecology of these landscapes started to come sharply into focus. We became aware that a whole host of microorganisms (readily visible fungi or blue green algae) had made their home in the vicinity of alum group minerals. Nowhere was this more evident than within or around hydrothermal vents (fumaroles) amidst the sparse solfataras of the SE of the island (PhotosJones et al. 2016, Fig. 4d). Once alerted to their presence, we began to be interested in the alum group minerals' microbiota (bacteria, fungi, algae, archaea), whether visible or not, and in the need to explore them further. Exposed minerals are often associated with a microbiome. Microbiome is defined as both the microbiota as well as what has been termed their 'theatre of activity' (Berg et al. 2020, Fig. 1). The latter is defined as: the structural elements (for example proteins/peptides, lipids, nucleic acids) of the microbial populations present; their biochemical constituents, 


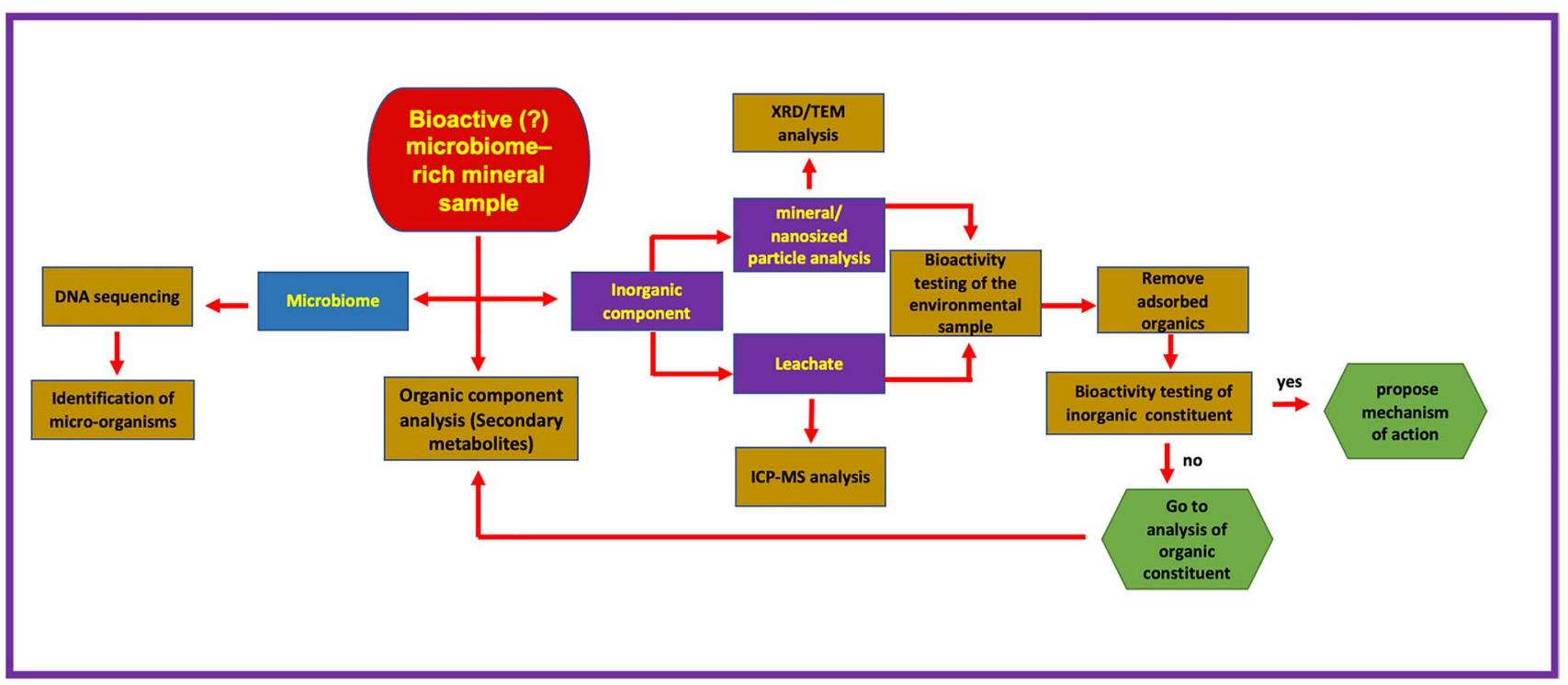

Fig. 1 Flowchart of the protocol of work, developed by our team, to test Greco-Roman medicinal minerals as antibacterials, including a. the characterization of the organic (microorganisms and their biomol-

secondary metabolites, i.e. organic compounds produced by the microorganisms in response to their environment which are not involved in their growth or reproduction; and thirdly, the environmental conditions prevailing in the ecological niche they find themselves in. So, the microbiome can be perceived as 'a community, its individual members, plus the 'contributions' of their everyday life'.

It is well known that the secondary metabolites of many bacteria and fungi are pharmacologically active (as antibacterial, antifungal, anticancer, antitumour, anti-inflammatory) (Shams ul Hassan et al. 2019). Therefore, in investigating G-R medicinal minerals an insight can be gained into natural minerals and their potential bioactivity. If G-R MMs were purported to be therapeutic could their bioactivity be derived from the mineral? its microbiome? or both?

The relationship between mineral and its microbiome is complex because it requires the elucidation of many parameters: for example, does the mineral act simply as a substrate? Or is it used as an energy source for the microorganism? Or is it used by the latter to produce new minerals? (Gross 2018). These questions are beyond the scope of this short study. However, it is known, from the texts, that natural medicinal minerals rarely underwent processing which would have resulted in the destruction of their microbiota, for example, through heating at high temperature. It follows that a substantial portion of the original microbiome (for example bioactive secondary metabolites) would have been carried into the ancient pharmacological recipe, with potentially beneficial (or detrimental) effect.

Given the above, we have devised a protocol of investigation which aimed to a. characterize the two components, ecules) and inorganic (minerals, their nanoparticles and leachates) components and $\mathbf{b}$. the bioactivity of each

the mineral and its biome, independently of each other and b. test the bioactivity of each (Fig. 1) (Photos-Jones et al. 2018; Christidis et al. 2020). Regarding sample characterization, the inorganic component is divided in the powder and the leachate: the former is subjected to mineralogical (at macro level with X-Ray Diffraction and at the nano-scale with Transmission Electron Microscopy) while the latter is subjected to chemical analysis (ICP-MS); the microbial community of the sample is subjected to DNA sequencing to identify the microorganisms present.

Bioactivity testing is focused on the leachate and what is measured is the minimum inhibitory concentration (MIC) of the sample (in $\mathrm{mg} / \mathrm{mL}$ ) that is required to reduce the bacterial colonies by more than $60 \%$. The leachate will carry both inorganic and organic components. Therefore, after measuring the $\mathrm{MIC}_{60}$ of the leachate, it is important to separate the organic from the inorganic component in order to test the bioactivity of each separately. The adsorbed organics are removed via oxidation and the (inorganic) leachate is tested again. If the inorganic component is inactive or considerably less bioactive than the original leachate then, it follows, that the organic component (the biomolecules representing secondary metabolites of the original microorganisms) must be the bioactive component; as such it needs to be investigated further via a series of analytical techniques that are best suited for the characterization of the biomolecules within.

Having presented our approach, we now turn to earth pigments of various colours. Ochres can vary considerably both in their geological context and in the choice of their use as artist's pigments. Yellow ochres consist of hydrated iron oxide $\mathrm{FeO}(\mathrm{OH}) \cdot \mathrm{H}_{2} \mathrm{O}$, limonite. Red ochres consist of the 
a

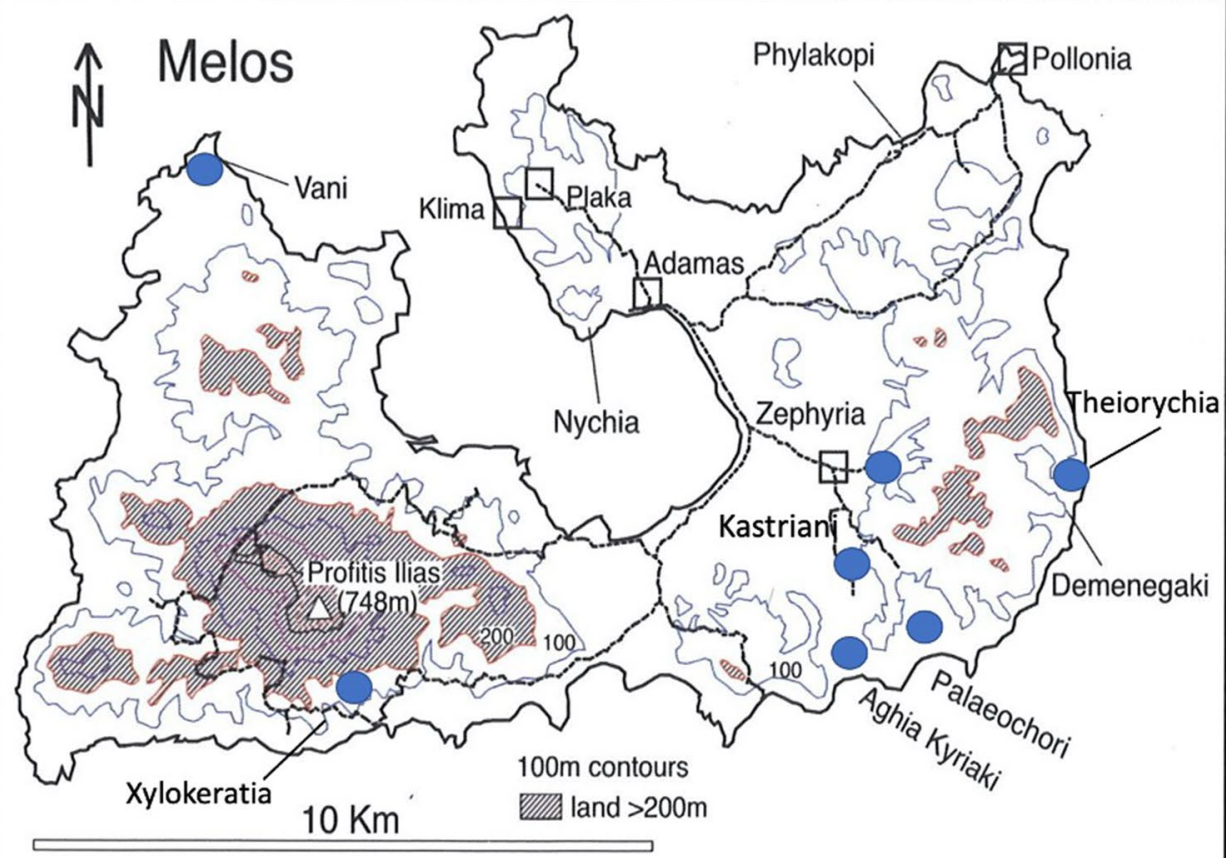

b

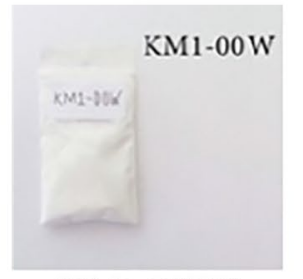

KM1-00W*

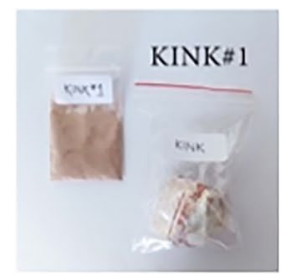

KINK-001

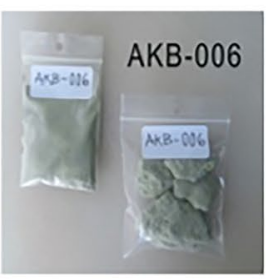

AKB-006

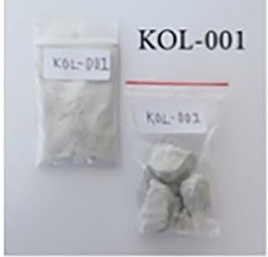

KOL-001

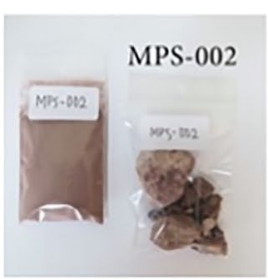

MPS-002

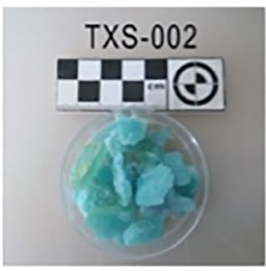

TXS-002*

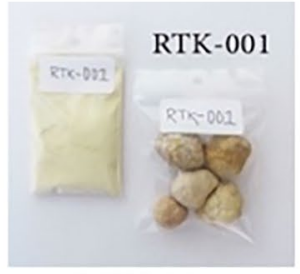

RTK-001*

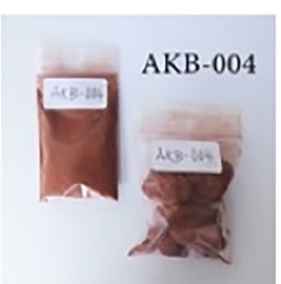

AKB-004*

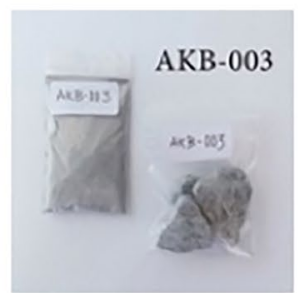

AKB-003*

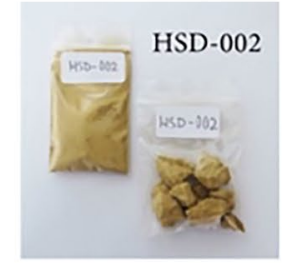

HSD-002

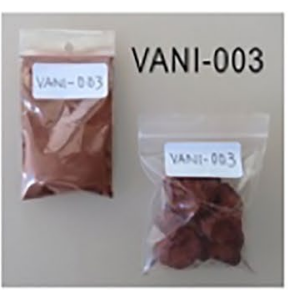

VAN-001

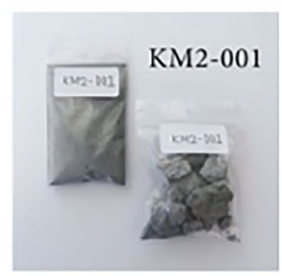

KM2-001

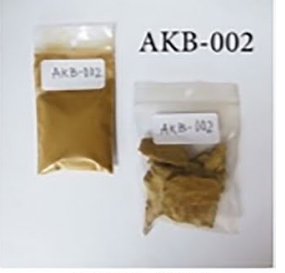

AKB-002

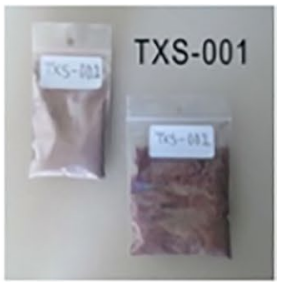

TXS-001*

VANI-002

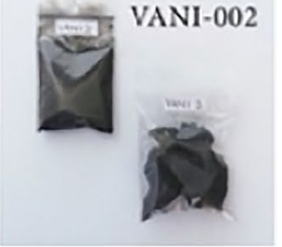

VAN-002*
Fig. 2 a Map of Melos with localities of sampling: $A K B=$ Aghia Kyriaki Bay; VAN = Vani; TXS $=$ Theiorychia; $\mathrm{MSP} / \mathrm{KM}=$ Paleochori bay; $\mathrm{HSD}=$ Xylokeratia; RTK $=$ Zephyria; $\mathrm{KOL} / \mathrm{KINK}=$ Kastriani. Nychia and Demenagaki $=$ obsidian sites; Phylakopi $=$ prehistoric site; Plaka/Adamas /Klima/Pollonia = modern settlements $($ map adapted from Photos-Jones and Hall 2014). b Samples of earth pigments collected from various localities shown in a. All samples have been subjected to mineralogical and DNA analyses. Those with a star $(*)$ have also been subjected to antimicrobial testing $\left(\mathrm{MIC}_{60}\right)$ 
mineral haematite $\mathrm{Fe}_{2} \mathrm{O}_{3}$ while brown ochres comprise the mineral goethite $\mathrm{FeO}(\mathrm{OH})$, (iron oxyhydroxide). Red/yellow 'ochres' can also derive from jarosite. Sienna and umber are mixtures of limonite with manganese oxide. 'Black earths' can also have an organic origin and result from the burning of wood (charcoal-soot). Green and blue earths are associated with glauconite and celadonite (Delamare and Guineau 2000; Eastaugh et al. 2004; Siddall 2018). The two sections below give a brief reference to the use of ochres in deep time (recent finds in Neanderthal/early modern human sites) and also to the use of red and white in the Greco-Roman world, before focusing attention on samples from the island of Melos, SW Aegean (Fig. 2a).

\section{About ochres, red miltos and the tetrachromia}

Ochres need no introduction to the archaeological record or literature. Specimens of red haematite were found away from source and in association with flint objects at an early Neanderthal site (Maastricht-Belvedere) dated to 200-250 ky in Europe (Roebroeks et al. 2012). In their review of the literature on sites in Africa and Europe with evidence of ochre use, Wolf et al. (2018, 186) write that, particularly from about 140 ky onwards, red/yellow/black earth pigments constitute, in quantity, the third most abundant archaeological find, after lithics and faunal remains. Manganese and iron oxides used in cave paintings in Spain, now dated to $65 \mathrm{ky}$ (Hoffmann et al. 2018) were probably worked by Neanderthals and not modern humans as previously thought. In Africa (Blombos Cave, South Africa) there is now evidence that early modern humans produced graphic designs on hardened mineral crust (silcrete) using a 'crayon' of red ochre (haematite) as early at $73 \mathrm{ky}$ ago (Henshilwood et al. 2018). This find predates by many thousands of years the cave art known from the Altamira (Spain) (c. 35-16 ky) and Lascaux (France) (c. $17 \mathrm{ky}$ ) caves. Cave art is based on the extensive use of metallic pigments, i.e. iron and manganese oxides for reds, yellows, browns and blacks and with whites provided by minerals like calcite and kaolinite (https://edu.rsc.org/resources/analy sis-of-cave-paintings/1586.article).

Beyond the realm of their use as pigments for body decoration and in art, ochres have had many other applications: as tanning agents (Dubreuil and Grosman 2009; Rifkin 2011), mosquito repellents (Rifkin 2015), photoprotective agents against the sun's UV radiation (Rifkin et al. 2015). Furthermore, their use as healing agents amongst huntergatherer groups has found advocates in J Velo (1986a, b); Velo relied on information provided by Peile (1979) on their traditional use by the Aborigines of Australia to cover wounds and to treat burns. Regarding their other uses in deep time (Neanderthals sites) some researchers have argued that 'manganese dioxide could also function as a combustive agent to produce fire on demand' (Heyes et al. 2016, in Wolf et al. 2018, 188). The above brief review merely aims to highlight the earth pigments' great antiquity and their wide range of applications in that time frame.

Coming to the Greco-Roman world, three particular ochres are noted by Dioscorides (Materia Medica Book V) for both their medicinal applications and as pigments. Yellow ochre (Mat. Med. V.93), was 'astringent, septic, dispersive of inflammations and growths'; White Melian earth (Mat. Med. V.159) could 'cleanse the body and give it a nice color, thin the hair, and cleanse dull-white leprosies'. Finally, red miltos (Mat. Med V.96) had 'astringent, desiccative, and adhesive properties on account of which it is compounded with plasters for wounds and with troches that dry and make costive' (English translations, Beck 2005). These three pigments formed part of the tetrachromia (fourcolour palette), the fourth colour being black. They were particularly favoured by the most illustrious painters of the Classical/Hellenistic and Roman periods. In his well-known passage, Pliny (Natural History Book 35, 50) declared that 'with only four colours, from the whites, Melian earth, from the yellows, ochre of Attica, from the reds Sinopic miltos and from the blacks atramentum did the illustrious painters Apellis, Aetion, Melathios, and Nichomachos produce their most immortal works'.

Miltos, the red ochre of the tetrachromia, had two acclaimed sources, Cappadocia, in central Turkey (Pliny Natural History Book 35, 30) and the island of Kea (Theophrastus

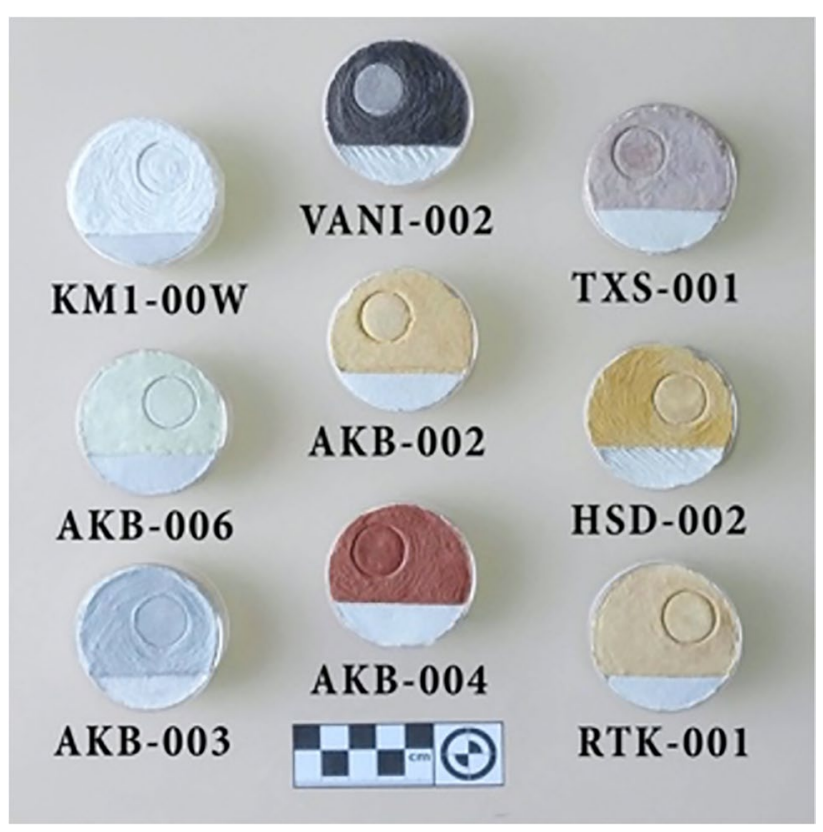

Fig. 3 Preparation of some of the samples as pigments for frescoes (see Fig. 2b and Appendix 2). VANI=VAN-002 
On Stones, 52). In the fourth century BCE, it was the latter that was the major producer of this mineral. Our team's work on Kea miltos has shown that it consisted of fine goethite and haematite, quartz, calcite and clay minerals (muscovite, illite, kaolinite) (Photos-Jones et al. 1997, Table 1; 2018). It was known for delivering a striking permanent red. Contemporary authors reported how Athenians, who attempted to abscond from their civic duties, were 'named and shamed' by being rounded off in the Agora with a rope dipped in miltos (Aristophanes Ecclesiazusae 379-380).

But miltos was more than a highly staining pigment. It had other properties/applications: i.e. as an antifouling agent, and in agriculture as both a fertilizer and as pest control (Lytle 2013). We demonstrated that Kea miltos' high content of $\mathrm{Pb}, \mathrm{Cu}, \mathrm{Cd}$ as well as a host of other metallic elements would have been toxic to marine life, therefore most effective as antifouling agent (Photos-Jones et al. 2018, Table 2). We have also shown, through sampling and analyses, that Kea miltos carried a host of micro-organisms which are able to convert atmospheric nitrogen to that absorbable by plant roots; this property alone of miltos' natural microbiome would have made miltos a good fertilizer.

Critical to our understanding of how miltos 'worked' is the understanding of the choice of medium in which it was dispensed. For miltos to be effective as an antifouling agent, the powder would have had to be mixed with an organic medium, as indeed fourth century BCE inscriptions from Athens (regarding the maintenance of civic walls) make clear when referring to the compound miltopitta (or miltopissa) (miltos-pitch/tar) (Lytle 2013, 537). For miltos to be effective as a fertilizer it would have to be 'dissolved' in water (a leachate of the original powder).

The focus of this study is red/yellow white, green and black earth pigments from the island of Melos, SW Aegean (Fig. 2a and b). The samples were surface collected by one of us (JGV), a local artist, and from different localities around the island; they were chosen for their suitability for use on plaster. Figure 3 illustrates JGV's work on plaster using some of the above pigments, while Appendices 1 and 2 provide an outline of the method of preparation and final application in the manner of buon fresco. In 'opting' to have a local artist guiding the present investigation, this enquiry aimed to take the Melos earth pigments at face value, i.e. as suitable materials for an artist's palette. Given that the texts ascribe medicinal properties to earth pigments, the question being asked here is: are any of these Melian pigments bioactive, i.e. antibacterial?

\section{Melos geology: A brief background}

Melos is situated in the SW part of the South Aegean Volcanic Arc. The geological framework of the island consists of four main units (Fytikas et al. 1986): (i) The Alpine metamorphic basement is characterized by a Middle Eocene high pressure/low temperature metamorphic event overprinted by a high temperature/low pressure one at the boundary between Oligocene and Miocene (Kornprobst et al. 1979; Hoffmann and Keller 1979); (ii) The

Table 1 Quantitative XRD analysis (\%) of Melos earth pigments; also four miltos pigments from Kea $(730.2,730.3,730.4,730.5)$ and two white alunogen/K-alum samples from Melos (LOU-1323 and LOU-1325). Samples marked with a $*$ have been tested for bioactivity

\begin{tabular}{|c|c|c|c|c|c|c|c|c|c|c|c|c|c|c|c|c|c|c|c|c|c|c|}
\hline & & White & White & $\begin{array}{l}\text { Pale } \\
\text { yellow }\end{array}$ & Yellow & Yellow & Yellow & \begin{tabular}{l|l|} 
Pale \\
Pink \\
\end{tabular} & Red & Red & Red & $\begin{array}{l}\text { Purple } \\
\text { Red }\end{array}$ & Red & Red & Red & $\begin{array}{c}\text { Pale } \\
\text { Green }\end{array}$ & \begin{tabular}{c|c|} 
Blue \\
Green
\end{tabular} & Grey & $\begin{array}{l}\text { Dark } \\
\text { Grey }\end{array}$ & Black & White & White \\
\hline Mineral & Mineral Formula & $\begin{array}{l}\text { KM1- } \\
\text { oow* }\end{array}$ & $\begin{array}{l}\text { KOL- } \\
001\end{array}$ & RTK-001* & $\begin{array}{l}\text { HSD- } \\
002\end{array}$ & \begin{tabular}{|c|} 
AKB- \\
O02
\end{tabular} & $730.3+$ & $\begin{array}{c}\text { KINK- } \\
001\end{array}$ & $\begin{array}{c}\text { MPS- } \\
002\end{array}$ & $\begin{array}{l}\text { AKB- } \\
004^{*}\end{array}$ & $\begin{array}{c}\text { VAN- } \\
003\end{array}$ & $\begin{array}{l}\text { TXS- } \\
\text { 001* }\end{array}$ & $\begin{array}{c}730.22 \\
+\end{array}$ & $\begin{array}{c}730.42 \\
+\end{array}$ & $\begin{array}{c}730.5 \\
+\end{array}$ & $\begin{array}{c}\text { AKB- } \\
006\end{array}$ & $\begin{array}{l}\text { TXS. } \\
002^{*}\end{array}$ & $\begin{array}{ll}\text { AKB- } \\
003^{*}\end{array}$ & KM2-001 & $\begin{array}{l}\text { VAM- } \\
\text { 002* }\end{array}$ & 1323 & 1325 \\
\hline Alunite & $\mathrm{KAl}_{3}\left(\mathrm{SO}_{4}\right)_{2}(\mathrm{OH})_{6}$ & 26.5 & & 75.6 & & & & & 3.8 & 5 & & 66.8 & & & & 4.3 & & 75 & 20.9 & & & \\
\hline Alunogen & $\mathrm{Al}_{2}\left(\mathrm{SO}_{4}\right)_{3} \cdot 17 \mathrm{H}_{2} \mathrm{O}$ & & & & & & & & & & & & & & & & & & & & 97.5 & 11.1 \\
\hline Alum-k & $\mathrm{KAl}\left(\mathrm{SO}_{4}\right)_{2} \cdot 11 \mathrm{H}_{2} \mathrm{O}$ & & & & & & & & & & & & & & & & & & & & 0.5 & 3.5 \\
\hline Anatase & $\mathrm{TiO}_{2}$ & 0.7 & & & & 1.4 & & & & & & & & & & 1.6 & & 1.1 & 0.9 & & & \\
\hline Ankerite & $\mathrm{Ca}(\mathrm{Fe}, \mathrm{Mg})\left(\mathrm{CO}_{3}\right)_{2}$ & & & & 24.4 & & & & & & & & & & & & & & & & & \\
\hline Barite & $\mathrm{BaSO}_{4}$ & & & & & & & & & & & & & & & & & & & 2.2 & & \\
\hline Calcite & $\mathrm{CaCO}_{3}$ & & & & 31.1 & & & & & & & & & 33.1 & 39.1 & & & & & & & \\
\hline Goethite & $\alpha-\mathrm{feO}(\mathrm{OH})$ & & & & 5.5 & 2.8 & 90.3 & & & & 20.3 & & 82.1 & 52 & \begin{tabular}{|c|c|c|}
39.7 & 0 \\
\end{tabular} & & & & 0.9 & & & \\
\hline Glauconite & $\mathrm{K}\left[\left(\mathrm{Al}, \mathrm{Fe}^{3 \mathrm{H}}\right)\left(\mathrm{Mg}, \mathrm{Fe}^{2+}\right)\right]\left[\mathrm{Al}_{0}, \mathrm{Si}_{1,1} \mathrm{O}_{10}\right](\mathrm{OH})_{2}$ & & & & & & & & & & 5.4 & & & & & & & & & & & \\
\hline Coquimbite & $\mathrm{AlFe}_{3}\left(\mathrm{SO}_{4}\right)_{6}\left(\mathrm{H}_{2} \mathrm{O}\right)_{12} \cdot 6 \mathrm{H}_{2} \mathrm{O}$ & & & & & & & & & & & & & & & & & & & & 1 & 1.4 \\
\hline Gypsum & $\mathrm{CaSO}_{4} \cdot 2 \mathrm{H}_{2} \mathrm{O}$ & & & & & & & & & & & & & & & & & & 14.7 & 1.8 & & \\
\hline Jarosite & $\mathrm{KFe}^{3+}{ }_{3}\left(\mathrm{SO}_{4}\right)_{2}(\mathrm{OH})_{6}$ & & & 23.3 & & & & & 0.4 & 3.7 & & & & & & & & & 6.4 & & & \\
\hline Halite & $\mathrm{NaCl}$ & 2.5 & & & & & & & & & & 0.1 & & & & & & 0.8 & & 2.1 & & \\
\hline Halotrichite & $\mathrm{FeAl}_{2}\left(\mathrm{SO}_{4}\right)_{4} \cdot 22 \mathrm{H}_{2} \mathrm{O}$ & & & & & & & & & & & & & & & & & & & & 0 & 4.3 \\
\hline Hematite & $\alpha \cdot \mathrm{Fe}_{2} \mathrm{O}_{3}$ & & & & & & 0.8 & & & & 6.4 & 2.1 & 17.9 & 8.1 & 7.1 & & & & & & & \\
\hline Hollandite & $\mathrm{Ba}\left(\mathrm{Mn}^{4+}{ }_{6} \mathrm{Mn}^{3+}{ }_{2}\right) \mathrm{O}_{16}$ & & & & & & & & & & & & & & & & & & & 28.8 & & \\
\hline Illite/mica & 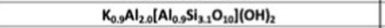 & & 11.6 & & 12.5 & 8.6 & & 39.1 & 32.5 & \begin{tabular}{|l|}
33.6 \\
\end{tabular} & & 1.6 & & & 6 & 27.7 & & & 28.8 & & & \\
\hline Kaolinite & $\mathrm{Al}_{2}\left(\mathrm{Si}_{2} \mathrm{O}_{5}\right)(\mathrm{OH})_{4}$ & 5.8 & 57.4 & & 10.4 & 32.8 & 6.5 & & 32.8 & 28.7 & 21.9 & 1.7 & & & 2.2 & 5.2 & & $\mid 17.4$ & & & & \\
\hline K-feldspar & $\mathrm{KAISI}, \mathrm{O}_{3}$ & & 1.4 & & & 11.4 & & & 2.8 & 4.7 & 43.7 & & & & & 4.4 & & & & 13.2 & & \\
\hline Maghemite & $\mathrm{Y} \cdot \mathrm{Fe}_{2} \mathrm{O}_{3}$ & & & & & & & & & & & & & & & & & & & 1 & & \\
\hline Melanterite & $\mathrm{Fe}^{2+}\left(\mathrm{H}_{2} \mathrm{O}\right)_{6} \mathrm{SO}_{4} \cdot \mathrm{H}_{2} \mathrm{O}$ & & & & & & & & & & & & & & & & 100 & & & & & \\
\hline $\begin{array}{l}\text { Mixed layer } \\
\text { Illite/smectite }\end{array}$ & $\begin{array}{l}\text { variable structural formula depending on the relative } \\
\text { proportion of end members }\end{array}$ & & & & & 19.4 & & & & 9.9 & & & & & & 8.7 & & & & 27.9 & & \\
\hline Natroalunite & $\mathrm{NaAl}_{3}\left(\mathrm{SO}_{4}\right)_{2}(\mathrm{OH})_{6}$ & & & & & & & & & 5.9 & & & & & & & & & & & & \\
\hline Opal-CT & $\mathrm{SiO}_{2} \cdot \mathrm{nH}_{2} \mathrm{O}$ & 63.5 & 12.5 & & & & & & & & & & & & & & & & & & & \\
\hline Plagioclase & $\mathrm{Na}\left(\mathrm{AlSi}{ }_{3} \mathrm{O}_{3}\right)$ to $\mathrm{Ca}\left(\mathrm{Al}_{2} \mathrm{Si}_{2} \mathrm{O}_{4}\right)$ & & 2.1 & & & 14.5 & & & 4.9 & & & & & & & 6.1 & & & & 14.1 & & \\
\hline Pickeringite & $\mathrm{MgAl}_{2}\left(\mathrm{SO}_{4}\right)_{4} \cdot 22 \mathrm{H}_{2} \mathrm{O}$ & & & & & & & & & & & & & & & & & & & & 0 & 72.4 \\
\hline Quartz & $\mathrm{SiO}_{2}$ & 1 & 13.9 & 1.1 & 16.1 & 9.1 & 2.4 & 60.9 & 19.3 & 8.5 & 2.3 & 27.7 & & 6.8 & 5.9 & 16.7 & & 5.7 & 27.4 & 4.9 & 0 & 6.4 \\
\hline Smectite & 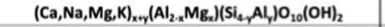 & & & & & & & & 3.5 & & & & & & & 22.9 & & & & & & \\
\hline Talc & $\mathrm{Mg}_{3} \mathrm{Si}_{4} \mathrm{O}_{10}(\mathrm{OH})_{2}$. & & 1.1 & & & & & & & & & & & & & 2.4 & & & & & & \\
\hline Todorokite & 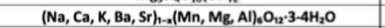 & & & & & & & & & & & & & & & & & & & 4 & & \\
\hline Voltaite & $\mathrm{K}_{2} \mathrm{Fe}_{2}+5 \mathrm{Fe}_{3}+3 \mathrm{AA} /\left(\mathrm{SO}_{4}\right)_{12} \cdot 18 \mathrm{H}_{2} \mathrm{O}$ & & & & & & & & & & & & & & & & & & & & 1 & 0.9 \\
\hline
\end{tabular}


Table 2 Chemical composition of leachates of the bioactive samples. Concentrations are in $\mathrm{ppm}(\mathrm{mg} / \mathrm{L}) . \mathrm{nd}=$ not detected. All entries rounded off to nearest whole number; concentrations presented as ' 0 ' denote trace amounts

\begin{tabular}{llll}
\hline & RTK-001 & VAN-002 & TXS-002 \\
\hline $\mathrm{B}$ & nd & 0 & nd \\
$\mathrm{Ca}$ & 18 & 12 & 15 \\
$\mathrm{Co}$ & nd & nd & 8 \\
$\mathrm{Cu}$ & nd & nd & 359 \\
$\mathrm{Fe}$ & 1 & 1 & 4758 \\
$\mathrm{~K}$ & 3 & 11 & nd \\
$\mathrm{Mg}$ & 0 & 6 & 5 \\
$\mathrm{Mn}$ & 0 & 6 & 5 \\
$\mathrm{Na}$ & 2 & 206 & 0 \\
$\mathrm{Ni}$ & nd & nd & 19 \\
$\mathrm{P}$ & 0 & 0 & 6 \\
$\mathrm{Zn}$ & nd & 0 & 13 \\
\hline
\end{tabular}

Neogene marine sedimentary sequence of Upper Miocene age (Fytikas et al. 1986); (iii) A volcanic sequence, which started in the Lower-Middle Pliocene (Fytikas et al. 1986; Stewart and McPhie 2006) and produced both pyroclastics and lavas, of rhyolite to low-Si andesite composition
(Fytikas et al. 1986; Stewart and McPhie 2006). The volcanic activity, which occurred under both subaerial and submarine conditions, was initiated in the western part of the island and migrated to the eastern part in the Upper Pliocene-Lower Quaternary (Fytikas et al. 1986; Stewart and McPhie 2006). Subsequent hydrothermal alteration of these volcanics gave rise to extensive bentonite deposits in the eastern part and small kaolin deposits mainly in the western part and the SE of the island as well as a series of shallow marine epithermal deposits in western Melos (Alfieris et al. 2013; Hein et al. 2013; Ivarsson et al. 2019). The fifteen samples shown in Fig. $2 b$ were collected from such areas of hydrothermal activity. Finally (iv) there are alluvial deposits, the most recent in the geological sequence.

\section{Method}

\section{Samples}

In this paper fifteen Melos pigment-samples (Fig. 2b) were chosen for analysis. For purposes of comparison, we have
Table 3 Abundances of bacteria (16S rRNA genes/g soil) and fungus (18S rRNA genes/g soil). *Minimum detection limit $=2000$ genes/g. Blueshaded: samples with high bioactivity; Orange-shaded: Loulos (non-pigment) samples used as 'controls'

\begin{tabular}{|c|c|c|c|}
\hline Sample & Colour & $\begin{array}{c}\text { Number of } \\
\text { bacteria }\end{array}$ & $\begin{array}{c}\text { Number of } \\
\text { fungus }\end{array}$ \\
\hline AKB-003 & light grey & BDL & BDL \\
\hline KOL-001 & white & 1600 & BDL \\
\hline AKB-002 & yellow & 5000 & BDL \\
\hline KM1-00W & white & 10000 & BDL \\
\hline AKB-004 & red & 20000 & BDL \\
\hline TXS-002 & green & 20000 & BDL \\
\hline MPS-002 & red & 20000 & BDL \\
\hline 730.2 & red & $<20000$ & - \\
\hline 730.4 & red & $<20000$ & - \\
\hline 730.5 & red & $<20000$ & - \\
\hline HSD-002 & yellow & 63000 & BDL \\
\hline TXS-001 & red & 100000 & BDL \\
\hline AKB-006 & green & 126000 & BDL \\
\hline RTK-001 & pale yellow & 200000 & 16000 \\
\hline KINK-1 & pink & 794000 & BDL \\
\hline VAN-002 & black & 1000000 & BDL \\
\hline LOU-1325 & white-non-pigment & 794000 & - \\
\hline LOU-1323 & white-non-pigment & 63000000 & - \\
\hline
\end{tabular}




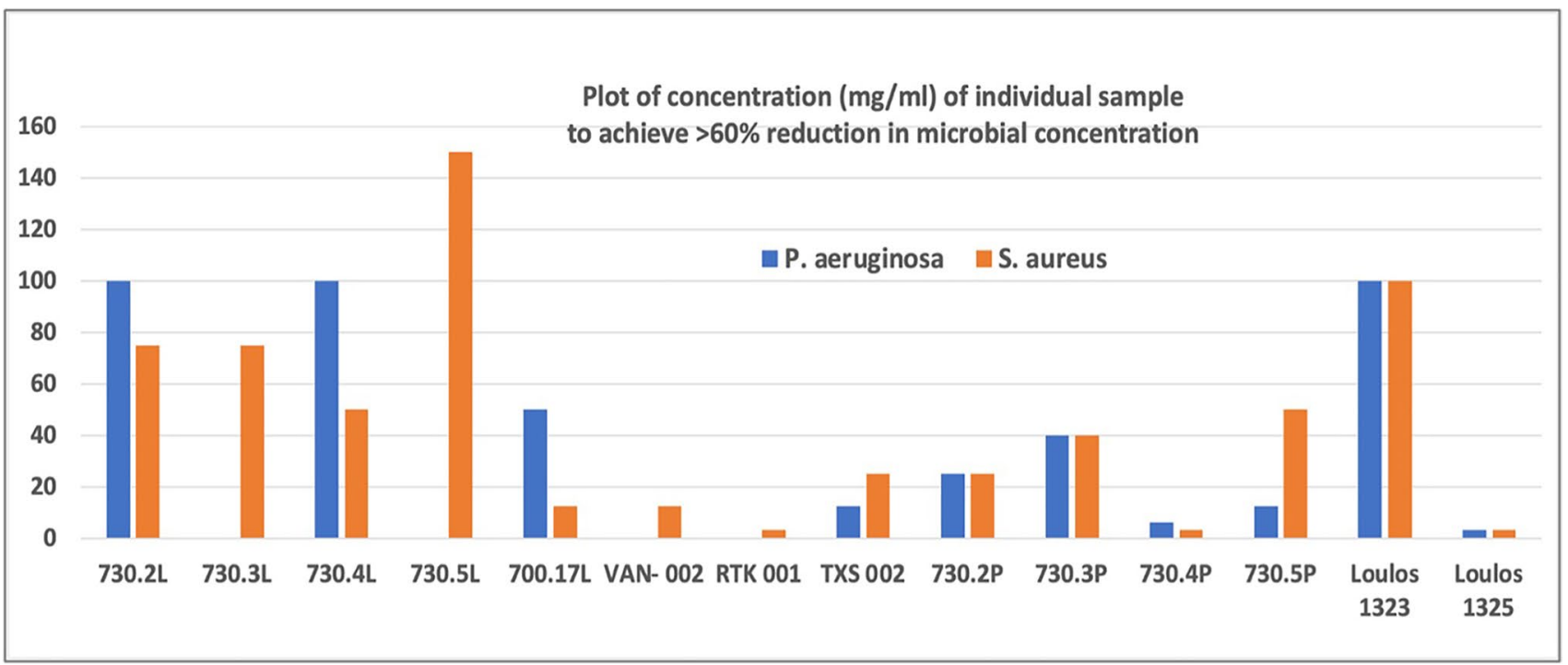

Fig. 4 Plot of $\mathrm{MIC}_{60}$. for Melos earth pigments and other samples discussed in the text. The smaller the $\mathrm{MIC}_{60}$ number, the higher the bioactivity of the said sample

also included: a. two, previously unpublished, non-pigment samples, also from Melos (Loulos 1323 and Loulos 1325). Loulos is a locality name to the $\mathrm{N}$ of Aghia Kyriaki Bay (Fig. 2a). The Loulos samples would not have been considered suitable as pigments on account of their high solubility. They are included here purely for purposes of comparison, one of them being highly bioactive (antibacterial). b. four, previously published, samples of Kea miltos (730.2-730.5). Of a total of twenty-one samples, twenty-one have been subjected to XRD analysis (Table 1); three to ICP-OES analysis (Table 2); sixteen to DNA analysis (Table 3); and seven samples to $\mathrm{MIC}_{60}$ testing, of which only three were shown to be bioactive (Fig. 4).

\section{XRD analysis}

The mineralogical composition of all samples was determined with X-ray diffraction (XRD), at the School of Mineral Resources Engineering, Technical University of Crete, on a Bruker D8 Advance Diffractometer equipped with a Lynx Eye strip silicon detector, using Ni-filtered $\mathrm{CuK} \alpha$ radiation $(35 \mathrm{kV}, 35 \mathrm{~mA})$. Data were collected in the $2 \theta$ range $3-70^{\circ} 2 \theta$ with a step size of $0.02^{\circ}$ and counting time $1 \mathrm{~s}$ per strip step (total time $63.6 \mathrm{~s}$ per step). The XRD traces were analysed and interpreted with the Diffrac Plus software package from Bruker and the Powder Diffraction Files (PDF). The quantitative analysis was performed on random powder samples using Al-holders (side loading mounting approach), by the Rietveld method using the BMGN code (Autoquan $\odot$ software package version 2.8).

\section{ICP-OES analysis of leachates}

The leachates of three bioactive samples were analysed by Inductively Coupled Plasma-Optical Emission Spectroscopy (ICP-OES) at the Mediterranean Agronomical Institute of Chania (MAICh) using an Agilent 5100 ICP-optical emission spectrometer. The detection limit of the method for analysed elements is less than $1 \mathrm{ppb}$. The precision of the analyses was tested using elemental standards for all major and trace elements $(1000 \mathrm{mg} / \mathrm{L})$ provided by Merck. The relative standard deviation of the analyses varied according to the concentration, typically $6 \%$ for the major elements, less for the trace elements.

\section{Organic carbon analyses}

Soil organic matter content as determined by loss of ignition (Hoogsteen et al. 2015). Pre-weighted samples were initially dried at $100{ }^{\circ} \mathrm{C}$ overnight, weighed $( \pm 0.1 \mathrm{mg})$, and then heated at $550 \mathrm{C}$ for $3 \mathrm{~h}$ (Nabotherm furnace). Correction procedure (Hoogsteen et al. 2015) were applied for structural water loss. Sample VAN-002 (5.0 mg, duplicate), subsequently discovered to have had significant carbon content, was analysed in duplicate by pyrolysis coupled to a two-dimensional chromatography with time-of-flight mass spectrometer, Py-GCxGC-ToFMS, at the University of Strathclyde (Glasgow, UK). A CDS Pyroprobe 6200 to $750{ }^{\circ} \mathrm{C}$ heated at a rate of $25^{\circ} \mathrm{C} / \mathrm{ms}$ connected directly into the Agilent $7890 \mathrm{~A}$ gas chromatography equipped with a LECO thermal modulator. The inlet $\left(310^{\circ} \mathrm{C}\right)$ was set to a 
split ratio of 75 with a helium flow rate of $1.4 \mathrm{~mL} / \mathrm{min}$. The column set up was reverse phase, 1 st dimension column Rxi17Sil MS (60 $\mathrm{m} \times 0.25 \mathrm{~mm}$ i.d. $\times 0.25 \mu \mathrm{m}$; Restek) polar phase, 2nd dimension column less polar phase Rxi-5Sil MS $(2.0 \mathrm{~m} \times 0.25 \mathrm{~mm}$ i.d. $\times 0.25 \mu \mathrm{m}$; Restek) less polar phase. The primary oven temperature programs were: initial at $50{ }^{\circ} \mathrm{C}$, hold for $0.2 \mathrm{~min}$, ramp $3.5^{\circ} \mathrm{C} / \mathrm{min}$ to $320^{\circ} \mathrm{C}$, hold for $20 \mathrm{~min}$. The secondary oven and thermal modulator had an offset of $+10{ }^{\circ} \mathrm{C}$ and $+20{ }^{\circ} \mathrm{C}$ respectively from the primary oven temperature. The thermal modulator period was $5 \mathrm{~s}$, and the transfer line temperature was $300{ }^{\circ} \mathrm{C}$. The detector was a LECO (St. Joseph, Michigan, USA) time of flight mass spectrometer (Pegasus 4D) with a spectra acquisition rate of 100 spectra/s. Different compound groups were identified by comparing pyrolusite's mass spectra to the NIST database (Linstrom and Mallard 2018).

\section{DNA analysis}

DNA extracted with Qiagen DNeasy PowerSoil extraction kit (with pre-incubation at $60^{\circ} \mathrm{C}$ for $10 \mathrm{~min}$ ). Similar handling and quality control measures were followed as according to Christidis et al. (2020). Each $20 \mu \mathrm{L}$ PCR reaction mixture consisted of $2 \mu \mathrm{L}$ of DNA sample, $5 \mu \mathrm{L}$ ssoFast Evagreen reagent (Bio-Rad), $1 \mu \mathrm{L}$ 10x-primer mixture $(0.2 \mu \mathrm{M}$ final concentration of each primer), and $2 \mu \mathrm{L}$ molecular-grade water. Reaction conditions were as follows, on a BioRad iCycler5 (BioRad, Hercules, CA USA) instrument: 3-min initial denaturation $\left(94^{\circ} \mathrm{C}\right)$; 40 cycles of: denaturation $\left(10 \mathrm{~s}\right.$ at $\left.94^{\circ} \mathrm{C}\right)$, primer annealing $(30 \mathrm{~s}$ at $58^{\circ} \mathrm{C}$ ). When completed, the instrument maintained the samples at $8{ }^{\circ} \mathrm{C}$. A post-analytical, high-resolution temperature-melt curve $\left(\Delta \pm 0.05^{\circ} \mathrm{C} / \mathrm{s}\right)$. Primers for 'total bacteria' (based on $16 \mathrm{~S}$ rRNA gene) were forward (AYTGGGYDTAAAGNG; position 563-577) and combined set of reverse (TACNVGGGTATCTA ATCC, TACCRGGGTHTCTAATCC, TACCAGAGTATCTAA TTC, and CTACDSRGGTMTCTAATC; position 907-924). Primers and PCR conditions targeting the 18S-rRNA gene of fungus were based on those by Hadziavdic et al. (2014).

\section{Antibacterial testing}

Antibacterial properties of the samples were tested using two reference bacterial indicators, namely the Gram-negative Pseudomonas aeruginosa NCTC 10662 and the Grampositive Staphylococcus aureus NCTC 12493. Both bacteria are often used as indicators in environmental studies and have been reported for their notable adaptability in stressed conditions and importance for public health issues.

The media used for their culture and growth were LB agar (LABM) and LB broth (LABM). Aqueous leachates of the samples were prepared with sterile deionized water at a concentration of $50 \mathrm{mg} / \mathrm{mL}$. Subsequently, ultrasonication was performed in an ultrasonic bath (Julabo) for $30 \mathrm{~min}$ at $25^{\circ} \mathrm{C}$, followed by centrifugation at $10,000 \mathrm{~g}$ for $15 \mathrm{~min}$ for the removal of all solids from the solution. The leachate was decanted and tested against the selected bacterial species for any growth inhibition.

Antimicrobial activity was assessed by means of the broth microdilution method and estimating the Minimum Inhibitory Concentration that inactivated $60 \%$ of the bacterial population $\left(\mathrm{MIC}_{60}\right)$. MIC is lowest concentration of an agent that will inhibit the visible growth of a microorganism after incubation. MICs were estimated labelling 96-well sterile microtiter trays with dilutions of each sample. The tested concentration range was $25-0.2 \mathrm{mg} / \mathrm{mL}$. Leachates were inoculated with liquid cultures and bacterial population was adjusted to $10^{5} \mathrm{CFU} / \mathrm{mL}$. The bioactivity of each sample was estimated in relation to positive control wells, which contained only the bacterial inoculum in LB broth. Microtiter trays were incubated at $37{ }^{\circ} \mathrm{C}$ for $18-24 \mathrm{~h}$, followed by optical density measurement at $630 \mathrm{~nm}$, using a microplate reader (Labtech LT-4000 Plate Reader) and Manta LML software.

\section{Results}

\section{XRD - Table 1}

Table 1 gives the compositions of the pigments and the minerals' formulae. As expected, mineralogy determines the colour of the samples. Those samples with white colour (KM1-00 W and KOL-001) are free of Fe-oxides, Feoxyhydroxides and/or Mn-oxides and Mn-oxyhydroxides. The yellow colour of samples AKB-002 and HDS-002 is attributed to minor goethite, whereas the red samples VAN001, AKB-004 and TXS-001 contain haematite with/without goethite. The pale green colour of sample AKB-006 is attributed to the presence of abundant smectite and minor talc. Samples with grey colours contain abundant alunite, whereas the black colour of VAN-002 is due to the presence of abundant hydrous Mn-oxides, namely hollandite and todorokite. Finally, the blue green of sample TXS-002 is due to melanterite $\left(\mathrm{FeSO}_{4} \cdot 7 \mathrm{H}_{2} \mathrm{O}\right)$. Table 1 also contains the mineralogical composition of miltos samples 730.2, 730.3, 730.4 and 730.5 (Photos-Jones et al. 2018) and two samples, from the locality of Loulos, SE Melos, in the proximity of a fumarole (gas emitting vent). As previously mentioned, the Loulos samples do not classify as earth pigments, being highly soluble on account of alunogen and pickeringite.

In comparing the Kea miltos samples with their red Melos equivalents it is noted that while the former are near-pure iron oxides, the latter would classify as clay-based iron oxides; this is on account of the enhanced levels of kaolinite. In other 
words, had they not been collected as pigments, by an artist, some of them may have been considered as simply red 'clays'.

\section{Analysis of leachates of the bioactive samples - Table 2}

Table 2 shows the results of the chemical analysis of the leachates of the three bioactive samples (see "Microbiology testing" section below). The leachates of RTK-001 and VAN-002 are essentially free of heavy metals $(\mathrm{Cu}, \mathrm{Co}, \mathrm{Ni}$, $\mathrm{Zn}$ ). Sample VAN-002 contains abundant $\mathrm{Na}$ and minor $\mathrm{Ca}$, $\mathrm{K}, \mathrm{Mg}$ and $\mathrm{Mn}$. By contrast, the leachate of TXS-002 is very rich in $\mathrm{Fe}$ and $\mathrm{Cu}$ and contains minor amounts of $\mathrm{Cu}, \mathrm{Co}$, $\mathrm{Ni}, \mathrm{Mn}$ and $\mathrm{Zn}$. The source of these elements must have been melanterite, a highly soluble mineral and the only one present in this sample. Bioactivity can relate to high concentrations of some metallic elements, hence the analyses presented in Table 2.

\section{Organic carbon and microbiological eDNA analysis - Table 3}

In any environment, bacterial populations are controlled by a number of parameters. These include: the toxicity of the substrates they may be growing on; the availability of energy (food) resource and conditions conducive to their growth $\left(\mathrm{pH}, \mathrm{O}_{2}\right.$, temperature or moisture); also, their inoculation potential (for example, can new bacteria establish themselves in location). Generally speaking bacterial populations in agricultural soils can be up to $10^{9}$ bacteria cells in a gram of soil. Table 3 gives an indication of bacterial (and fungal, if appropriate) populations in each sample.

Bacteria concentrations in the earth pigments presented here and measured in genes per gram, are very low. They range from $10^{3.3}$ (1600) to $10^{6.0}$ ( 1 million) genes per gram (Table 3), based on the 16S-rRNA (small subunit ribosome) gene content, a common surrogate measure of the "total bacteria" present (Woese and Fox 1977). The levels detected here are multiple orders of magnitude lower than those normally expected in terrestrial environments which usually range from $10^{6}$ to $10^{9}$ cells per gram. Bacteria numbers for samples 730.2, 730.4 and 730.5, discussed in a previous publication (Photos-Jones et al. 2018), are also low, as are bacteria numbers for sample LOU-1325, provided here for comparison. Fungal DNA was only detectable in a single sample, i.e. RTK-001; however, here again levels were slightly above analytical detection limits.

In short, with the exception of VAN-002, all the earth pigments show a considerable paucity of organic content. The only sample with high organic load is LOU-1323. We proceed to investigate closer the nature of the organic load.

Loss of ignition (LOI) was carried out on all samples. With the exception of VAN-002 (LOI=6\%), LOI was found to be minimal (ranging from $<1 \%$ to $4 \%$ ). However, once corrected for structural water loss in clay fraction (Hoogsteen et al. 2015 ), with the exception of VAN-002, values were $<2 \%$, often near $0 \%$. This corresponds with previously reported equally low estimates for LOIs in samples obtained from the region (e.g. Georgoulias and Moustakas 2010).

Pyrolysis (Py-GCxGC-ToFMS analysis) identifies thermally degraded parts of larger organic compounds within samples. Compound identification is carried out by comparing pyrolysis mass spectra to the NIST database (Linstrom and Mallard 2018). With the exception of VAN-002, low concentrations of organics were found in all. Aliphatic compounds, such as branched and n-alkenes, cyclo-alkenes, organic acids and alcohols, are present in all samples, as were mono aromatic compounds (e.g. phenol, toluene, p-xylene, o-xylene). The latter form between 0.6 and $6 \%$ of the composition of different samples. We examine here three samples in particular: VAN-002, AKB-002 and AKB-004.

Regarding AKB-002, the main constituent component $(46 \%)$ is alpha-methylstyrene, most likely a product of plastic breakdown. Other components which contribute a further $42 \%$ are acetaldehyde, a commonly occurring compound found in nature and cyclopentane ethyl ethylene. Regarding AKB-004, 76\% was made up of $\mathrm{N}$-alkenes, indicating longer chain aliphatic.

Finally, regarding VAN-002, the main pyrolysis products, making up over $65 \%$ were diazene, dimethyl- (32.5\%) and benzene (32.5\%). Both products represent the breakdown of plant materials. Benzene is possibly derived from lignins (Zakzeski et al. 2010; Wu et al. 2017). On the other hand, diazins can represent pyrimidines (e.g., nucleic acids) but also many natural products and biologically active compounds (e.g. Rinderspacher 2014). The remainder pyrolysis components in VAN-002 included alkanes (consisting of 1-heptene (2.5\%), 1-octene (2.6)), acetic acid (7.3\%), undecanoic acid (5.2\%), oxy-acetic acid (3.0\%), and cyclohexanone $(1.6 \%)$.

\section{Microbiology testing - Fig. 4}

Antibacterial testing was performed on seven samples of the earth pigments (TXS-002, KM-00 W, AKB-004, RT-001, TXS-001, AKB-003 and VAN-002): Fig. 4 shows the $\mathrm{MIC}_{60}$ values of only the samples which were found to be bioactive together with those already reported for miltos from Kea (Photos-Jones et al. 2018, 730.2-730.5) and also previously unpublished samples for Loulos (1323 and 1325). All MICs are carried out on leachates with the exception of samples 730.2P, 730.4P, 730.5P which were powders.

The results show that only three earth pigments were bioactive against $P$. aeruginosa and $S$. aureus. Specifically, TXS-002, RTK-001 and VAN-002 inhibited bacterial growth with $\mathrm{MIC}_{60}$ ranging from 25 to $3.12 \mathrm{mg} / \mathrm{mL}$. The samples 
VAN-002 (black manganese minerals) and RTK-001 (yellow jarossite) exhibited antibacterial properties only in the case of $S$. aureus, highlighting the different resistance level and behaviour between the two selected bacterial indicators. On the other hand, TXS-002 (melanterite) was active against both species. We point out that the $\mathrm{MIC}_{60}$ values of these three earth pigments were much lower (more bioactive) than those measured for the four samples $(730.2 \mathrm{~L}-730.5 \mathrm{~L})$ from Kea and one sample from Loulos (1323). These samples should not, in principle, be considered bioactive, taking into account that inhibitory concentrations for $60 \%$ of bacterial reduction were $50-300 \mathrm{mg} / \mathrm{mL}$. Values comparable with the three earth pigments derived only from 730.4P (a powder) and Loulos 1325 (a leachate).

\section{Discussion}

Establishing whether an earth pigment may or may not be bioactive (as antibacterial/antifungal/antioxidant) is a complex question requiring an understanding of: a. the nature (mineralogical/chemical) and ecology of the particular mineral combination; $b$. the nature of its carrier (aqueous vs. organic). Each sample is examined on its own merit and, so far, there are no overriding criteria as to why some earth pigments, of one or more colours, are antibacterial.

The method we have developed builds up a 'picture' of each sample under investigation by profiling its inorganic (mineralogical/geochemical) and organic (microbiome/ organic molecules characterization) components. We also test the bioactivity of the leachate (water mixed with powdered sample and subsequently separated from it). Only three samples (black VAN-002, green TXS-002 and paleyellow RTK-001) displayed considerable antibacterial activity. On the other hand, red, jarosite-containing AKB004, white, alunite-containing KM1-00 W and AKB-003, and haematite-containing TXS-001 displayed no bioactivity. Similarly low bioactivity was detected in the leachates of the yellow/red Kea miltos $730.2 \mathrm{~L}, 730.3 \mathrm{~L}, 730.4 \mathrm{~L}$ with $730.5 \mathrm{~L}$ being non-bioactive. Contrary to their leachates, the powdered samples $730.2 \mathrm{P}, 730.3 \mathrm{P}, 730.4 \mathrm{P}$, $730.5 \mathrm{P}$ were bioactive.

Figure 4 combines the results for three samples (VAN002, TXS-002, RTK-001) with those of previous work on leachates of miltos $(730.2,730.3,730.4,730.5)$; the latter containing nanoparticles (average size $<200 \mathrm{~nm}$ ) of Feoxides/oxyhydroxides, with minor quartz and mica, have shown limited bacteriostatic activity. On the other hand, the same samples, as powders, showed better bacteriostatic activity, with $\mathrm{MIC}_{60}$ values from $3.12 \mathrm{mg} / \mathrm{mL}$ upwards (Photos-Jones et al. 2018).

Sample TXS-002 consists of melanterite, an $\mathrm{Fe}^{2+}$-bearing hydrous sulphate. During preparation of the leachate, melanterite, which is soluble in water, will release $\mathrm{Fe}^{2+}$ and $\mathrm{SO}_{4}{ }^{2-}$ ions. It is expected that the presence of free $\mathrm{Fe}^{2+}$ ions in the leachate will induce antibacterial activity via a Fenton-type oxidation reaction, i.e. reaction of $\mathrm{Fe}^{+2}$ with $\mathrm{H}_{2} \mathrm{O}_{2}$, resulting in the generation of free radicals (reactive oxygen species- ROS) which are detrimental to bacteria. This is because Fenton reactions cause oxidative stress on outer cell wall components and this stress can be expanded towards the cytoplasmic membrane, altering cell permeability and leading to the leakage of intracellular components (Cagnasso et al. 2010; Morrison et al. 2016; Williams 2017).

The bioactivity of TXS-002, against both pathogens tested here, verifies the substantial oxidizing power of ROS in effectively reducing microbial populations. S. aureus was slightly more resistant; as a Gram-positive bacterium, possessing a thick cell wall, it indicates the higher resistance of that bacterial group under certain environmental conditions (Venieri and Mantzavinos 2017). Additionally, dissolution of melanterite during preparation of leachate released high amounts of $\mathrm{Cu}$ and minor amounts of $\mathrm{Co}, \mathrm{Ni}, \mathrm{Zn}$ and $\mathrm{Mn}$, all hosted in melanterite. Copper and $\mathrm{Zn}^{2+}$ ions have widely been reported as having antibacterial properties (e.g. Otto and Haydel 2013). In our study, the release of large amounts of $\mathrm{Cu}^{2+}$ in the leachate of TXS-002 (Table 2) is bound to affect the antibacterial properties of this sample.

The leachate of RTK-001 also displayed bioactivity (Table 3, Fig. 4). The composition of this sample includes minerals, such as alunite, jarosite and quartz, with very low solubility in water. Therefore, the bioactivity of this leachate cannot be explained in terms of ROS, as in the case of TXS002. RTK-001 is the only sample with a fungal load as well as a small bacterial load, albeit just above the level of detection. It is not clear whether this combined (bacteria+fungi) organic load is responsible for the bioactivity displayed by RTK-001.

VAN-002 has, again, a different mineralogical composition to the above two earth pigments. It contains Fe-oxides and Fe-oxyhydroxides (haematite and goethite) which are also not soluble. In addition, it is free of $\mathrm{Fe}^{2+}$-bearing phases but contains abundant Mn-phases (hollandite and todorokite). This sample also stands apart in having the highest abundance of bacteria $\left(\right.$ c. $\left.10^{6}\right)$. These features likely contribute to its considerable antibacterial activity, because they are both expected to be present in the leachate due to their nanoparticle size (Bloise et al. 2020). Todorokite has been shown to have remarkable oxidative properties and to degrade organic compounds, such as dyes. In oxidizing conditions, the active Mn centers of todorokite evolve rapidly through $\mathrm{Mn}^{3+} / \mathrm{Mn}^{4+}$ causing fast catalytic degradation of the dyes (Bletsa et al. 2020). Since todorokite and hollandite contain both $\mathrm{Mn}^{3+}$ and $\mathrm{Mn}^{4+}$, hollandite is expected to display similar behaviour to todorokite. The presence of minor 
$\mathrm{Mn}$ in the leachate of VAN-002 (Table 2) is in accordance with this suggestion.

Further to the above, VAN-002 contains numerous organic compounds, as described in section 3.2, linked to bacteria populations. The most abundant organic compounds detected in VAN-002 are benzene, diazene, and acetic acid. Benzene rings have been shown to display antibacterial properties (Taleb et al. 2017) and acetic acid has antiseptic properties. Therefore, the organic compounds identified in VAN-002, might also contribute to its antibacterial properties. However, this sample was active only against $S$. aureus and had no effect on the $P$. aeruginosa population. This maybe the case because $P$. aeruginosa often exhibits tolerance under stressed conditions, as an opportunistic pathogen (Makropoulou et al. 2018).

We turn now to the overall lack of biomass (with the exception of VAN-002) in the earth pigments examined here and the poor levels of preservation of their bacterial/fungal biome, as demonstrated from pyrolysis analysis. This lack of biomass could be due to the lack of nutrient and resource availabilities needed for the growth of the microbial communities, minimal exposure for inoculation, or environmental toxicities (due to the chemistry of the substrate and/or sunlight/UV radiation exposure (Gutiérrez-Cacciabue et al. 2016; Nelson et al. 2020). Ultraviolet light can not only initiate DNA damage which will affect microbial survival but can also photolytically reduce organic carbon content.

However, although we acknowledge that exposure to UV radiation might have played a role, we note that the miltos samples which originated from within mines in Kea, also displayed low organic load (Table 3). The latter may or may not be attributed to long storage (samples were collected from these mines more than 20 years ago; Photos-Jones et al. 1997).

TXS-002 and RTK-001 were both bioactive but their bioactivity is likely to be abiotic in nature, i.e. not deriving from secondary metabolite production. VAN-002 was an exception to the above. The black earth pigment had a $6 \%$ organic content and a bacterial count of $10^{6}$ cells/g. VAN-002 had biological activity against $S$. aureus, only. As mentioned, todorokite, one of its constituent minerals, is known for its oxidative properties. It is not clear what the contribution (to bioactivity) of the organic component might be.

\section{Conclusions}

Since the start and throughout our work with G-R medicinal minerals we have assumed that some, if not all, must have been pharmacologically active. In our attempt to put them to 'a test' we begun assessing them for their bioactivity as antibacterials. As our work evolved, we have argued that the origin of that bioactivity is difficult to pinpoint conclusively and can, in principle, derive either from the mineral's inorganic component or its organic load; or both. Furthermore, that antibacterial activity between powders and leachates of the same sample, can vary.

Amongst the Melos and Kea earth pigments presented here, amount of organic load varied considerably. We showed that the majority of the red/yellow (Melos and Kea miltos) samples did not have a rich bacterial/ fungal load. Melos pale-yellow RTK-001 contained both a small bacterial and a fungal load. But it was the black manganese-rich Melos VAN-002 that was particularly bacteria-rich.

As to which component contributed mostly to bioactivity: in the case of the green pigment TXS-002, it maybe the mineral component thereof (i.e. $\mathrm{Fe}^{+2}$ and $\mathrm{Cu}^{+2}$ in melanterite) that took a leading role, if it contributed to the generation of ROS via Fenton-type reactions (for $\mathrm{Fe}^{+2}$ ). On the other hand, in the black earth pigment VAN-002, the Mn-rich mineral todorokite, is known to display oxidative powers in degrading organic compounds; but it also appeared not to hinder the growth of bacterial populations. In this case, both Mn ions and the sample's microbiome may be driving this particular sample's bioactivity. From the above, it follows that similarity in colour cannot imply similarity in bioactivity. Yellowish-white RTK-001 is bioactive but equally yellowish-white AKB-002 is not (Fig. 3).

We conclude that the mechanism(s) driving the bioactivity of the inorganic world (rocks and minerals) and our evolving understanding of it, is far from being elucidated. This is on account of the complex interactions between the organic and inorganic constituent parts at the interface between ecology, mineralogy and bioactivity. Nevertheless, this short paper, albeit preliminary, helps in keeping the discussion ongoing and relevant. We argue that the G-R texts, with their often detailed empirical observations and descriptions of minerals, as pigments, and their inclusions in pharmacological recipes, as therapeutics, can guide and inform this investigation.

\section{Appendix 1. by J. Gibney-Vamvakari}

The following gives a short account of the treatment of nine of the fifteen samples as shown in Fig. 3. For the preparation of these samples the buon fresco (true fresco) technique was used. Each sample was mixed with deionized water and applied onto fresh, wet lime plaster with an artist's paintbrush and limewater (lime putty diluted with deionized water). Buon fresco uses no other binder than the lime in the wet plaster. 


\section{AKB-002}

This sample was found as a soft, solid piece with layers of yellow ochre of different shades and with a strong distinctive smell of soil/rust. It broke up easily into sheets and was ground down easily in a mortar. It needed repeated rounds of levigation to remove the remaining brown colour/impurities. As a fine, non-staining, pigment powder, it seemed to have tiny particles that glistened. It painted onto wet plaster easily as an opaque pigment and dried to a dull ochre yellow.

\section{AKB-003}

This sample was found as small, compact pieces on sand, most likely having been washed there by rain. It had subtle layers of slightly different colours and crushed easily with a mortar and pestle. It was levigated to remove any sand or debris to become a non-staining opaque paint.

\section{AKB-004}

This sample was found as a saturated red, compact lump. It was, sieved, ground in a mortar and finally levigated to remove impurities. It was then mulled with water. The final pure pigment was staining and opaque when applied onto plaster. The colour lightened slightly as the plaster dried but still remained strongly saturated.

\section{AKB-006}

This sample was found combined with sand, and organic impurities. It was processed by levigation; the final, pure pigment was extremely fine so the final test grinding for impurities, in a mortar, was minimal. The pigment was unsaturated and non-staining and was applied easily to wet plaster. The colour lightened as the plaster dried into a nonsaturated, dull green.

\section{KM-00 W}

This sample was found as a fine, crisp white powder that was noticeably brighter in comparison to other 'white' samples found on Melos. It was sieved to remove any minute impurities and levigated once to test for the possibility of a 'brighter' white pigment. Once the levigation water had completely cleared, no top layer of 'brighter' white pigment was distinguishable on the settled white pigment, only a thick top layer that appeared more luminescent, possibly due to its fineness. When removed from the levigation water, the pigment had a lustrous appearance and unique tactile properties, keeping its form when manipulated but reverting to a fine powder when dry. It was ground and mulled before being painted onto the plaster and remained bright as the plaster dried.

\section{RTK-001}

This sample was found as a solid concretion, initially difficult to break up and grind. It was repeatedly ground in a mortar and sieved to become a fine even-coloured powder that was not levigated as it had no visible impurities. The resulting pigment was bright, opaque and non-staining with a creamy consistency that painted easily onto wet plaster. While drying, the pigment slowly changed from bright yellow to an orange/red colour, possibly reverting back to the reddish tones of jarossite.

\section{HSD-002}

was found fallen from a small cliff of the same material, as a large solid piece that was soft after rain. It crushed easily with a mortar and pestle into a fine powder, which was not initially levigated as it seemed pure and clean with no obvious impurities such as grit or plant roots. It became a creamy, easy to use opaque pigment, and when levigated separated into a darker and lighter hue with the same properties.

\section{TXS-001}

This sample was found as a soft, pink powder combined with mineral and organic impurities. It was sieved and levigated many times resulting in a very fine powder; it required minimal grinding. This non-staining pigment was applied easily to wet plaster and lightened slightly when dry.

\section{VAN-002}

This sample was collected as fist-sized black lumps. It was sieved and ground to become a heavily staining, fine, black powder. It was not levigated. The pigment was applied easily to wet plaster and lightened slightly when dry.

\section{Appendix 2. by J. Gibney-Vamvakari}

\section{Colour Swatches}

Lime plaster was chosen as the substrate for colour swatches. Using the buon fresco technique, the prepared pigments, ground in water, were applied to the final smooth, wet plaster layer (the intonaco). Over time the pigments merge with the plaster to become an integral part of the surface due to the process of carbonation when the lime putty slowly reverts back to limestone. The lime plaster consisted of an aggregate (river sand) and mature lime putty. 
To ensure the river sand was not contaminated with silt or clay, it was meticulously washed in rainwater and repeatedly rinsed in deionized water. This was the most time-consuming part of the prep process. Once the sand was absolutely dry it was sieved with a 40 and 60 mesh sieve.

Two batches of lime plaster were made: Batch 1 was made for the first two layers of plaster by using 2 parts of $40 \mathrm{~m}$ sand to 1 part lime putty; Batch 2 was made for the final smooth intonaco layer using 1 part $60 \mathrm{~m}$ sand to 0.75 parts lime putty. Both were thoroughly mixed (with no extra water) sealed in airtight containers and allowed to rest for at least $24 \mathrm{~h}$ before use.

Before each use, the plaster was well kneaded with artist palette knives to make it more pliable. The base of each dish was lined with a disc of hessian fabric previously soaked in deionized water.

\section{Layer 1}

$25 \mathrm{~g}$ of plaster from batch 1 was pressed into the base of the dish with artist palette knives and the surface left rough to allow the next layer to adhere/meld easily. It was allowed to dry thoroughly which can take days, depending on weather conditions.

\section{Layer 2}

Once dry the base layer was brushed to remove any loose particles and well moistened with deionized water. $15 \mathrm{~g}$ of plaster from batch 1 was pressed onto the base layer and the surface smoothly and neatly finished. This second layer wasn't allowed to dry before the next layer was applied.

\section{Layer 3}

$10 \mathrm{~g}$ of plaster from batch 2 was added immediately for the final intonaco layer, the surface was carefully and neatly smoothed with artist palette knives and scored with painting guidelines.

Painting onto the intonaco layer started immediately. The colour swatches for this project were made with three layers of lime plaster specifically prepared for small-scale work (using fine grades of sand) and $6 \mathrm{~cm}$ plastic petri dishes as containers (see Fig. 3).

Funding The work is part of a larger study into Greco-Roman antimicrobial minerals funded by the Wellcome Trust (Seed Award in the Humanities and Social Sciences (201676/Z/16/Z, PI: E. Photos-Jones). We would like to thank Dr. T. Nikoli, Soil Science Laboratory, MAICh, for the ICP-OES analyses; also the three anonymous reviewers whose constructive reviews helped improve the text.
Open Access This article is licensed under a Creative Commons Attribution 4.0 International License, which permits use, sharing, adaptation, distribution and reproduction in any medium or format, as long as you give appropriate credit to the original author(s) and the source, provide a link to the Creative Commons licence, and indicate if changes were made. The images or other third party material in this article are included in the article's Creative Commons licence, unless indicated otherwise in a credit line to the material. If material is not included in the article's Creative Commons licence and your intended use is not permitted by statutory regulation or exceeds the permitted use, you will need to obtain permission directly from the copyright holder. To view a copy of this licence, visit http://creativecommons.org/licenses/by/4.0/.

\section{References}

Aceto M (2021) The palette of organic colourants in wall paintings. Archaeol Anthropol Sci. https://doi.org/10.1007/ s12520-021-01392-3

Alfieris D, Voudouris P, Spry PG (2013) Shallow submarine epithermal $\mathrm{Pb}-\mathrm{Zn}-\mathrm{Cu}-\mathrm{Au}-\mathrm{Ag}-\mathrm{Te}$ mineralization on western Milos Island, Aegean volcanic Arc, Greece: mMineralogical, geological and geochemical constraints. Ore Geol Rev 53:159-180

Arizzi A, Cultrone G (2021) Mortars and plasters - How to characterise hydraulic mortars. Archaeol Anthropol Sci. https://doi.org/10. 1007/s12520-021-01404-2

Beck LY (2005) Pedanius Dioscorides of Anazarbus, De materia medica, transl., Altertumswissenschaftliche Texte und Studien, Band 38, Hildesheim, Olms-Weidmann

Becker H (2021) Pigment nomenclature in the ancient Near East, Greece, and Rome. Archaeol Anthropol Sci. https://doi.org/10. 1007/s12520-021-01394-1

Berg et al (2020) Microbiome definition re-visited: old concepts and new challenges. Microbiome 8:103. https://doi.org/10.1186/ s40168-020-00875-0

Bletsa E, Zaccone C, Miano T, Terzano R, Deligiannakis Y (2020) Natural Mn-todorokite as an efficient and green azo dye-degradation catalyst. Environ Sci Pollut Res 27:9835-9842. https://doi. org/10.1007/s11356-019-07524-6

Bloise A, Miriello D, De Rosa R, Vespasiano G, Fuoco I, De Luca R, Barrese E, Apollaro C (2020) Mineralogical and geochemical characterization of Asbestiform Todorokite, Birnessite, and Ranciéite and their host Mn-rich deposits from Serra D'Aiello (southern Italy). Fibers 8(2):9. https://doi.org/10.3390/fib8020009

Burgio L (2021) Pigments, dyes and inks - their analysis on manuscripts, scrolls and papyri. Archaeol Anthropol Sci. https://doi. org/10.1007/s12520-021-01403-3

Cagnasso M, Boero V, Franchini MA, Chorover J (2010) ATR-FTIR studies of phospholipid vesicle interactions with $\alpha-\mathrm{FeOOH}$ and $\alpha-\mathrm{Fe}_{2} \mathrm{O}_{3}$ surfaces. Colloids Surfaces B Biointerfaces 76:456-467. https://doi.org/10.1016/j.colsurfb.2009.12.005

Caroselli M, Ruffolo SA, Piqué F (2021) Mortars and plasters - How to manage mortars and plasters conservation. Archaeol Anthropol Sci. https://doi.org/10.1007/s12520-021-01409-x

Cavallo G, Riccardi MP (2021) Glass-based pigments in painting. Archaeol Anthropol Sci (forthcoming)

Christidis GE, Knapp CW, Venieri D, Gounaki I, Elgy C, ValsamiJones E, Photos-Jones E (2020) The interweaving roles of mineral and microbiome in shaping the antibacterial activity of archaeological medicinal clays. J Ethnopharmacol 260:112894. https:// doi.org/10.1016/j.jep.2020.112894

DeLaine J (2021) Production, transport and on-site organisation of Roman mortars and plasters. Archaeol Anthropol Sci. https://doi. org/10.1007/s12520-021-01401-5 
Delamare F, Guineau B (2000) Colour: making and using dyes and pigments. Thames and Hudson

Domingo Sanz I, Chieli A (2021) Characterising the pigments and paints of prehistoric artists. Archaeol Anthropol Sci. https://doi. org/10.1007/s12520-021-01397-y

Dubreuil L, Grosman L (2009) Ochre and hide-working at a Natufian burial place. Antiquity. https://doi.org/10.1017/S0003598X0 0099269

Eastaugh N, Walsh V, Chaplin T, Siddall R (2004) The pigment compendium: a dictionary of historical pigments. Elsevier - Butterworth Heineman, Oxford

Ergenç D, Fort R, Varas-Muriel MJ, Alvarez de Buergo M (2021) Mortars and plasters - How to characterise aerial mortars and plasters. Archaeol Anthropol Sci. https://doi.org/10.1007/ s12520-021-01398-x

Fytikas M, Innocenti F, Kolios N, Manneti P, Mazzuoli R, Poli G, Rita F, Villari L (1986) Volcanology and petrology of volcanic products from the island of Milos and neighbouring islets. J Volcanol Geotherm Res 28:297-317

Georgoulias FA, Moustakas NK (2010) Exploration of soils developing on volcanic materials on the island of Milos, Greece. Catena $81: 43-54$

Gliozzo E (2021) Pigments - Mercury-based red (cinnabar-vermilion) and white (calomel) and their degradation products. Archaeol Anthropol Sci. https://doi.org/10.1007/s12520-021-01402-4

Gliozzo E, Burgio L (2021) Pigments - Arsenic-based yellows and reds. Archaeol Anthropol Sci. https://doi.org/10.1007/ s12520-021-01431-z

Gliozzo E, Ionescu C (2021) Pigments - Lead-based whites, reds, yellows and oranges and their alteration phases. Archaeol Anthropol Sci. https://doi.org/10.1007/s12520-021-01407-z

Gliozzo E, Pizzo A, La Russa MF (2021) Mortars, plasters and pigments - Research questions and sampling criteria. Archaeol Anthropol Sci. https://doi.org/10.1007/s12520-021-01393-2

Gross M (2018) Mining the mineral microbiome. Curr Biol 28:R1325-R1334

Gutiérrez-Cacciabue D, Cid AG, Rajal VB (2016) How long can culturable bacterial and total DNA persist in environmental waters? The role of sunlight and solid particles. Sci Total Environ 539:494502. https://doi.org/10.1016/j.scitotenv.2015.07

Hadziavdic K, Lekang K, Jonassen I, Thompson EM, Troedsson C (2014) Characterization of the 18S rRNA gene for designing universal eukaryote specific primer. PLoS One. https://doi.org/10. 1371/journal.pone.0087624

Hall A, Photos-Jones E (2008) Accessing past beliefs and practices: the case of Lemnian earth. Archaeometry 50(6):1034-1049. https:// doi.org/10.1111/j.1475-4754.2007.00377.x

Hall AJ, Fallick AE, Perdikatsis V, Photos-Jones E (2003a) A model for the origin of AI-rich efflorescences near fumaroles, Melos, Greece: enhanced weathering in a geothermal setting. Mineral Mag 67(2):363-379. https://doi.org/10.1180/0026461036720102

Hall AJ, Photos-Jones E, McNulty A, Turner D, McRobb A (2003b) Geothermal activity at the archaeological site of Aghia Kyriaki and its significance to Roman industrial mineral exploitation on Melos, Greece mineral exploitation on Melos, Greece. Geoarchaeology: An International Journal 18(3):333-357. https://doi. org/10.1002/gea.10068

Hein JR, Stamatakis MG, Dowling JS (2013) Trace metal-rich quaternary hydrothermal manganese oxide and barite deposit, Milos Island, Greece. Trans Instn Min Metall (Sect B: Appl earth sci) 109:B67-B76

Henshilwood CS, d'Errico F, van Niekerk KL et al (2018) An abstract drawing from the 73,000-year-old levels at Blombos cave, South Africa. Nature 562:115-118. https://doi.org/10.1038/ s41586-018-0514-3
Heyes PJ, Anastasakis K, de Jong W, van Hoesel A, Roebroeks W, Soressi M (2016) Selection and use of manganese dioxide by Neanderthals. Sci Rep 6:1-9

Hoffmann C, Keller J (1979) Xenoliths of lawsonite-ferroglaucophane rocks from a quaternary volcano of Milos (Aegean Sea, Greece). Lithos 12:209-219

Hoffmann DL, Standish CD, García-Diez M, Pettitt PB, Milton JA, Zilhão J, Alcolea-González JJ, Cantalejo-Duarte P, Collado H, de Balbín R, Lorblanchet M, Ramos-Muñoz J, Weniger G-CH, Pike AWG (2018) U-Th dating of carbonate crusts reveals Neandertal origin of Iberian cave art. Science 359(6378):912-915. https:// doi.org/10.1126/science.aap7778

Hoogsteen MJJ, Lantinga EA, Bakker EJ, Groot JCJ, Tittonell PA (2015) Estimating soil organic carbon through loss on ignition: effects of ignition conditions and structural water loss. Eur J Soil Sci 66(2):320-328. https://doi.org/10.1111/ejss.12224

Ivarsson M, Kilias SP, Broman C, Neubeck A, Drake H, Chi Fru E, Bengtson S, Naden J, Detsi K, Whitehouse MJ (2019) Exceptional preservation of Fungi as H2-bearing fluid inclusions in an Early Quaternary Paleo-hydrothermal system at Cape Vani, Milos, Greece. Minerals 9:749. https://doi.org/10.3390/min9120749

Kornprobst J, Kienast J-R, Vilminot J-C (1979) The high-pressure assemblages at Milos, Greece. Contrib Mineral Petrol 69:49-63

La Russa MF, Ruffolo SA (2021) Mortars and plasters - How to characterise mortars and plasters degradation. Archaeol Anthropol Sci. https://doi.org/10.1007/s12520-021-01405-1

Lancaster LC (2021) Mortars and plasters - How mortars were made. The Literary Sources. Archaeol Anthropol Sci. https://doi.org/10. 1007/s12520-021-01395-0

Linstrom PJ, Mallard WG (2018) NIST Chemistry WebBook, NIST Standard Reference Database Number 69. National Institute of Standards and Technology Gaithersburg MD, 20899. https://doi. org/10.18434/T4D303

Lytle E (2013) Farmers into sailors: ship maintenance, Greek agriculture, and the Athenian monopoly on Kean Ruddle (IG II ${ }^{2} 1128$ ). Greek Roman Byzantine Stud 53:520-550

Makropoulou T, Panagiotopoulou P, Venieri D (2018) N-doped $\mathrm{TiO}_{2}$ photocatalysts for bacterial inactivation in water. J Chem Technol Biotechnol 93:2518-2526

Mastrotheodoros GP, Beltsios KG, Bassiakos Y (2021) Pigments Iron-based red, yellow and brown ochres. Archaeological and Anthropological Sciences (forthcoming)

Morrison KD, Misra R, Williams LB (2016) Unearthing the antibacterial mechanism of medicinal. A Geochemical Approach to Combating Antibiotic Resistance Scientific Reports, Clay. https://doi. org/10.1038/srep19043

Murat Z (2021) Wall paintings through the ages. The medieval period (Italy, 12th-15th century). Archaeol Anthropol Sci. https://doi.org/ 10.1007/s12520-021-01410-4

Nelson KS, Boehm AB, Davies-Colley RJ, Dodd MC, Kohn T, Linden KG, Liu Y, Maraccini PA, McNeill K, Mitch WA, Nguyen TH, Parker KM, Rodriguez RA, Sassoubre LM, Silverman AI, Wiggington KR, Zepp RG (2020) Sunlight-mediated inactivation of health-relevant microorganisms in water: a review of mechanisms and modeling approaches. Environmental Science Processes and Impacts 20(8):1089-1122

Otto CC, Haydel SE (2013) Exchangeable ions are responsible for the in vitro antibacterial properties of natural clay mixtures. PLoS One 8:1-9. https://doi.org/10.1371/journal.pone.0064068

Peile AR (1979) Colors that cure. Hemisphere 23(4):214-217

Pérez-Arantegui J (2021) Not only wall paintings - Pigments for cosmetics. Archaeol Anthropol Sci. https://doi.org/10.1007/ s12520-021-01399-w

Photos-Jones E, Hall AJ (2011) Lemnian earth and the earths of the Aegean: an archaeological guide to medicines, pigments and washing powders. Potingair Press, Glasgow 
Photos-Jones E, Hall AJ (2014) Eros, Mercator and the cultural landscape of Melos in antiquity. Potingair Press, Glasgow

Photos-Jones E, Knapp CW, Venieri D, Christidis GE, Elgy C, Valsami-Jones E, Gounaki I, Andriopoulou NC (1997) Kean Miltos: the well-known iron oxides of antiquity. Annual of the British School at Athens 92:359-371. https://doi.org/10.1017/S0068 245400016737

Photos-Jones E, Keane C, Jones AX, Stamatakis M, Robertson P, Hall AJ, Leanord A (2015) Testing Dioscorides' medicinal clays for their antibacterial properties: the case of Samian earth. J Archaeol Sci 57:257-267. https://doi.org/10.1016/j.jas.2015.01.020

Photos-Jones E, Christidis GE, Piochi M, Keane C, Mormone A, Balassone G, Perdikatsis V, Leanord A (2016) Testing Greco-Roman medicinal minerals: the case of solfataric alum. J Archaeol Sci Rep 10:8295. https://doi.org/10.1016/j.jasrep.2016.08.042

Photos-Jones E, Christidis G, Barrett B (2017a) Stevenson at Vulcano in the late 19th century: a Scottish mining venture in southern Europe. Proc Soc Antiqu Scotl 147:303-323. https://doi.org/10. 9750/PSAS.147.1255

Photos-Jones E, Edwards C, Häner F, Lawton L, Keane C, Leanord A, Perdikatsis V (2017b) Archaeological medicinal earths as antibacterial agents: the case of the Basel Lemnian sphragides. Geol Soc Lond, Spec Publ 452(1):141-153. https://doi.org/10.1144/ SP452.6

Photos-Jones E, Knapp CW, Venieri D, Christidis GE, Elgy C, Valsami-Jones E, Gounaki I, Andriopoulou NC (2018) GrecoRoman mineral (litho)therapeutics and their relationship to their microbiome: the case of the red pigment miltos. J Archaeol Sci Rep 22:179-192. https://doi.org/10.1016/j.jasrep.2018.07.017

Rifkin RF (2011) Assessing the efficacy of red ochre as a prehistoric hide tanning ingredient. Journal of African Archaeology 9(2):131-158

Rifkin RF (2015) Ethnographic and experimental perspectives on the efficacy of red ochre as a mosquito repellent. South African Archaeological 70:64-75

Rifkin, R.F., Laure Dayet, Alain Queffelec, Francesco d'Errico, Beverley Summers, and Marlize Lategan. (2015) Evaluating the photoprotective effects of red ochre on human skin by in vivo SPF assessment: implications for human evolution, adaptation and dispersal. PLoS One 10 (9): e0136090. https://doi.org/10.1371/ journal.pone.0136090

Rinderspacher KA (2014) Six-membered ring systems: diazines and benzo derivatives. In: Progress in Heterocyclic Chemistry 26: 395 ISSN 0959-6380

Roebroeks, W. M. J. Sier, Trine Kellberg Nielsen, Dimitri De Loecker, Josep Maria Parés, Charles E. S. Arps, and Herman J. Mücher (2012) Use of red ochre by early Neanderthals. PNAS 109 (6) 1889-1894; https://doi.org/10.1073/pnas.1112261109

Salvadori M, Sbrolli C (2021) Wall paintings through the ages. The Roman period: Republic and early Empire. Archaeol Anthropol Sci. https://doi.org/10.1007/s12520-021-01411-3
Shams ul Hassan S, Jin H, Abu-Izneid T, Rauf A, Ishaq M, Suleria HAR(2019) Stress-driven discovery in the natural products: A gateway towards new drugs. Biomed Pharmacother 109:459-467. https://doi.org/10.1016/j.biopha.2018.10.173

Siddall R (2018) Mineral pigments in archaeology: their analysis and the range of available materials Minerals, 8(5), 201. https://doi. org/10.3390/min 8050201

Stewart AL, McPhie J (2006) Facies architecture and Late PliocenePleistocene evolution of a felsic volcanic island, Milos, Greece. Bull Volcanol 68:703-726

Švarcová S, Hradil D, Hradilová J, Čermáková Z (2021) Pigments Copper-based greens and blues. Archaeol Anthropol Sci. https:// doi.org/10.1007/s12520-021-01406-0

Taleb K, Mohamed-Benkada M, Benhamed N, Saidi-Besbes S, Grohens Y, Derdour A (2017) Benzene ring containing cationic gemini surfactants: synthesis, surface properties and antibacterial activity. J Mol Liq 241:81-90. https://doi.org/10.1016/j.molliq. 2017.06.008

Velo J (1986a) Ochre as medicine: a suggestion for the interpretation of the archaeological record. Curr Anthropol 25(5):674

Velo J (1986b) The problem of ochre. Mank Q 26(3):229-237

Venieri D, Mantzavinos D (2017) Disinfection of Waters/Wastewaters by Solar Photocatalysis (Chapter 8). Advances in Photocatalytic Disinfection, edited by Taicheng An, Huijun Zhao and Po Keung Wong. https://doi.org/10.1007/978-3-662-53496-0 @ Springer

Vitti P (2021) Mortars and masonry - Structural lime and gypsum mortars in Antiquity and Middle Ages. Archaeol Anthropol Sci. https://doi.org/10.1007/s12520-021-01408-y

Williams LB (2017) Geomimicry: harnessing the antibacterial action of clays. Clay Miner 52:1-24

Woese CR, Fox GE (1977) Phylogenetic structure of the prokaryotic domain: the primary kingdoms. PNAS 74(11):5088-5090. https:// doi.org/10.1073/pnas.74.11.5088

Wolf $\mathrm{S}$ et al (2018) The use of ochre and painting during the upper Paleolithic of the Swabian Jura in the context of the development of ochre use in Africa and Europe. Open Archaeol 4:185-205. https://doi.org/10.1515/opar-2018-0012

Wu X-P, Fan M-H, Li Q-X (2017) Production of benzene from lignin through current enhanced catalytic conversion. Chines J Chem Phys 30(4):479-468

Zakzeski J, Bruijnincx PCA, Jongerius AL, Weckhuysen BM (2010) The catalytic valorization of lignin for the production of renewable chemicals. Chem Rev 110(6):3552-3599

Publisher's note Springer Nature remains neutral with regard to jurisdictional claims in published maps and institutional affiliations. 